\title{
41. HISTORY OF ASTRONOMY (HISTOIRE
}

\section{DE L'ASTRONOMIE)}

President: O. Gingerich.

Vice-President: W. Hartner.

Organizing Committee: J. O. Fleckenstein, C. D. Hellman, Z. Horský, M. A. Hoskin, P. G. Kulikovsky, E. Rybka; O. Pedersen, representative of the International Union for the History and Philosophy of Science.

\section{INTRODUCTION}

The interval between the Fourteenth and Fifteenth General Assemblies was marked by two major anniversaries: 1971, the 400th year after the birth of Kepler, and 1973, the 500th year after the birth of Copernicus. In proclaiming 1973 'the Year of Copernicus', the General Assembly in Brighton offered to astronomers a special opportunity to reflect on the historical development of our science, on the obstacles to its progress, and on the conditions for the flowering of creative thought.

The importance of studying Copernicus and Kepler as archetypal figures in the growth of science has never been more clearly understood. For example, a recently developed physics curriculum for high school students in America devotes one out of six major units to the astronomical revolution of Copernicus, Tycho, Kepler, Galileo, and Newton because no clearer illustration of the changing nature of the scientific world view could be found. In an age when the value of scientific progress is increasingly challenged, a thoughtful and perceptive reexamination of those ancient but remarkable steps in understanding the universe can do nothing less than help to rekindle the spirt of inquiry into the world about us. Today, when scientists often take the brunt of a mystical anti-intellectualism, the history of astronomy can provide a particularly interesting and helpful area for studying the creative human aspects of science.

A very exciting prospect has now arisen: Many persons who will never take the time to write their own history of astronomy will be prepared to contribute their expertise to a series of volumes containing a vivid and accurate story of the growth of astronomy. A General History of Astronomy, on the scale envisioned by our Commission, would furnish a significant reference tool for the working scientist, the historian of science, or the teacher of science. The encouraging progress on this project is reported below in section IV, but if the international character of this undertaking (so earnestly desired by the Commission) is to be achieved, further funds must be obtained for translations and to guarantee an extensive distribution and review of the draft chapters.

This report of Commission 41 does not aspire to present a comprehensive review of the activities carried out in the past three years by historians of astronomy. Nevertheless, the list of books in section IX gives some hint of the diversity of research in this field, and the other sections report on selected highlights of interest to the Commission.

\section{MEMBERSHIP}

A characteristic feature of Commission 41 is that many eminent scholars, active workers in the history of astronomy but not astronomers, serve as consulting members of the Commission though they are not regular members of the IAU. At present the Commission is composed of 59 members and 34 consulting members. In 1970 the Commission successfully coopted into full IAU membership Prof. E. Rosen (U.S.A.), Dr M. A. Hoskin (U.K.), and Prof. W. Hartner (G.F.R.).

In times past a few professional astronomers, such as J.-B. Delambre, J. L. E. Dreyer, and the late E. Zinner, have brought expert scholarship to the study of problems in the history of astronomy. 
There have been other astronomers, however, who have casually ventured into this field, writing without a knowledge of original sources; they would scarcely have tolerated such a disregard for data in their own areas of specialty. This amateur effort created an impression that the treatment of historical problems was a trivial exercise, best left to retired astronomers.

Happily, the professionalism that now characterizes the work of Commission 41 has earned a new respect for the validity of historical problems for serious research. Nevertheless, the IAU must recognize that the historians of astronomy who have been trained professionally as historians of science, rather than as astronomers per se, are playing an absolutely essential role in establishing the standards for this field. If Commission 41 is to remain both professional and representative, the IAU must continue on occasion to admit into full membership experts in the history of astronomy who are not practicing astronomers.

A proposal to form a common commission between the IAU and the International Union for the History and Philosophy of Science (IUHPS) could not be formally realized because of the entirely different membership structure of the two unions. Nevertheless, for practical purposes the cooperation is maximized because essentially the same persons organize the history of astronomy activities in both unions. Furthermore, with the agreement of the IAU Executive Committee, the IUHPS now appoints a representative to our Organizing Committee. At present Prof. O. Pedersen (Denmark), Treasurer of the IUHPS, serves as IUHPS representative on the Commission 41 Organizing Committee.

\section{COMMISSION PUBLICATIONS}

The president has continued the publication of the Information Circular, printed in Cambridge by the Smithsonian Astrophysical Observatory. Numbers 19, 20, and 21 have appeared since the Fourteenth General Assembly in Brighton, and another is planned for the spring of 1973. The Circulars contain names and addresses of our consulting members, as well as various information on the General History of Astronomy, on symposia and anniversary celebrations, and on the census of rare books in the history of astronomy, particularly Copernicus' De Revolutionibus. The Circulars are distributed free to all members and consulting members of Commission 41.

Issues 11 and 12 of the Bibliography of Books and Papers Published on the History of Astronomy for 1969-1971 appeared in a joint issue in 1972. These were prepared by N. B. Lavrova (Sternberg Astronomical Institute, Moscow) and edited by $\operatorname{Dr} Z$. K. Sokolovskaya, with the help of L. M. Vasil'eva. The bibliography lists approximately 700 titles.

\section{GENERAL HISTORY OF ASTRONOMY}

The idea of a multi-volume General History of Astronomy (GHA) had its inception in our Commission under Dr P. G. Kulikovsky (U.S.S.R.) and Prof. E. Rybka (Poland). At the Thirteenth General Assembly of the IAU in Prague (1967), a resolution was adopted that recognized the importance and usefulness of preparing an international history of astronomy based on original materials. Following the General Assembly in Brighton, the project gained momentum owing to the desire of the IUHPS to become a cosponsor. Dr Hoskin was selected to serve as general editor, and the MIT Press (Cambridge, Massachusetts, U.S.A.) has agreed to support the publication. The following persons will plan and supervise this undertaking as members of the Editorial Advisory Board:

O. Gingerich (U.S.A), Chairman (IAU/IUHPS)

M. Hoskin (U.K.), General editor (ex officio)

$$
I A U
$$

W. Hartner (G.F.R.)

P. G. Kulikovsky (U.S.S.R.)

E. Rybka (Poland)

G. J. Whitrow (U.K.)

\section{IUHPS}

I. B. Cohen (U.S.A.)

Z. Horský (Czechoslovakia)

J. Needham (U.K.)

O. Pedersen (Denmark)

R. Taton (France) 
A meeting of the Editorial Advisory Board of the GHA took place in Krakow, Poland, on 28-29 August, 1972, and the following decisions were reached. The history will be organized in four volumes. Volume 1 will include the astronomy of antiquity through Copernicus. Volume 2 will include the work of Tycho, Kepler, Galileo, Newton and contemporaries, Laplace, to the discovery of Neptune. Volume 3 will overlap partially in time, emphasizing sidereal astronomy, e.g., Herschel's work, galactic structure, celestial mapping, astrometry, and statistical astronomy, perhaps up to Kapteyn. Volume 4 will emphasize astrophysics (beginning with the spectroscope and photography around 1860), but will include other 20th century topics to around 1930-1940. More recent developments in the 20th century will be covered not by individual chapters but by an extensive annotated critical bibliography that lists both reviews and the key original contributions.

The volume editors will be:

\section{Volume $1 \quad$ O. Pedersen (Denmark)}

Volume 2 R. Taton (France), with three assistants covering special areas

Volume 3 M. A. Hoskin (U.K.) and P. G. Kulikovsky (U.S.S.R.)

Volume 4 G. Whitrow (U.K.)

The final organization of chapters and the selection of authors will be the responsibility of each volume editor in consultation with the general editor. The volume editors will then contact the authors and collect the manuscripts. They will read the manuscripts and (in consultation with the general editor) send the manuscript chapters to appropriate referees. It is particularly important, when there are conflicting viewpoints, to guarantee that alternative views are properly significant represented.

On the other hand, matters of style, translation, and illustrations will be left in the hands of the general editor, who will provide the principal interface with the publisher.

The organizational meeting of the Editorial Advisory Board was financed from a grant of blocked zloty funds awarded by the Smithsonian Institution, Washington, D.C.

\section{JOURNAL FOR THE HISTORY OF ASTRONOMY}

In 1973 the Journal for the History of Astonomy begins its fourth volume under the editorship of M. A. Hoskin. The journal has published articles over a broad range of topics, from the alignments of the Carnac megaliths to the Michelson-Morley-Miller experiments, and from the classification of Indian planetary tables to Newton's maturing thoughts on dynamical astronomy. The journal also contains book reviews, notes of meetings, and lists of dissertations on the history of astronomy.

This journal is of the greatest importance for communication in our field of study, because it counteracts the tendency for articles in the history of astronomy to become hidden in publications that we do not ordinarily see. Nevertheless, any journal this specialized necessarily faces a precarious financial existence.

The JHA was originally published by Macdonald and Company in London, but more recently it has been taken over by Science History Publications, Ltd., c/o Dr M. A. Hoskin, Churchill College, Cambridge, England. This change represents an effort to guarantee the future existence and stability of the journal. Members of the Commission and their institutions are urged to help ensure the viability of the journal by subscribing to it.

\section{KEPLER ANNIVERSARY - 1971}

Special exhibitions and symposia honoring the 400th anniversary of Johannes Kepler's birth were staged in several cities in both Europe and America during 1971.

In Weil der Stadt, Germany, where Kepler was born in 1571, scholars from seven countries met on 9-11 August to discuss 'little known aspects' of Kepler's work. These papers were scheduled 
for publication in 1972 under the title Internationales Kepler-Symposium Weil der Stadt 1971 (edited by Fritz Krafft, Karl Meyer, and Bernhard Sticker). In the house of the Kepler Commission in Weil der Stadt, some of Kepler's books and original manuscripts were exhibited.

On display at the University of Tübingen, where Kepler studied, were portraits, books, and manuscripts illustrating his links with this institution. Especially noteworthy were originals of Kepler's grades and several autograph books that he had signed for his friends. A very informative catalog of the exhibition, Kepler und Tübingen, has been prepared by Dr Frederich Seck.

In Prague, where Kepler worked very fruitfully from 1600 to 1612 , a major exhibition in the Belvedere Palace showed the rich cultural setting of that time. Astronomical instruments, works of art, books, and photographic murals were imaginatively arranged under the direction of $\mathrm{Dr} \mathrm{Z}$. Horský. Included was an oil painting from Castle Rychnov, recently identified as a contemporary portrait of Kepler by Hans von Aachen, a court artist of Prague in the early 1600 s.

In the Austrian city of Linz, Kepler's home from 1612 to 1627 , the high school was renamed in his honor during the symposium on 13-14 August. A particularly beautiful collection of books and instruments from several countries was displayed in the Steinerne Saal of the Linzer Landhaus, a hall through which Kepler must have passed on several occasions. Unique copies of several rare almanacs by Kepler, an early sextant that he is believed to have used, and another newly identified portrait were on display. A 179-page catalog, Johannes Kepler, Werk und Leistung, organized by Dr Wilhelm Freh, Director of the Oberösterreiches Landesmuseum, contained 13 articles by Kepler specialists from Germany, Austria, and America.

The many manuscripts left at Kepler's death in 1630 were purchased in 1773 by Catherine the Great for the St. Petersburg Academy of Sciences. Most of these volumes were on display in the Leningrad Planetarium on 26-28 August during a Kepler symposium held in conjunction with the Thirteenth International Congress for the History of Science. The following papers were given:

Yu. Biely (U.S.S.R.)

G. A. Chebotarev (U.S.S.R.)

V. P. Chenakal (U.S.S.R.)

W. Gerlach (G.F.R.)

O. Gingerich (U.S.A.)

D. Hellman (U.S.A.)

K. Hujer (U.S.A.)

N. M. Raskin (U.S.S.R.)

I. I. Shafranovsky (U.S.S.R.)

A. Simon (France)

J. Smorodinsky and Yu. Danilov (U.S.S.R.)

V. Thoren (U.S.A.)

H. J. Treder (D.D.R.)

R. S. Westman (U.S.A.)

C. A. Wilson (U.S.A.)
'Kepler and the Development of Mathematics'

'Johann Kepler and Celestial Dynamics'

'Kepler's Astronomical Instruments'

'Johannes Kepler - Leben, Mensch und Werk'

'The Origin of Kepler's Third Law'

'Kepler and Comets'

'Johann Kepler in Prague'

'On Kepler's Manuscripts in the Archives of the Academy of Sciences of the U.S.S.R.'

'Johann Kepler, the Founder of Structural Crystallography'

'l'Astrologie de Kepler'

'Kepler and Modern Physics'

'Kepler on the Lunar Theory'

'Kepler and the Theory of Gravitation'

'Kepler's Theory of Hypothesis'

'Kepler's Ellipse and Area Rule: Their Derivation from Fact and Conjecture'

The Leningrad commemoration was the Second Joint Symposium of the IAU and IUHPS, the first having been the symposium in Hamburg in 1964. Prof. A. A. Mikhailov, Honorary President of the symposium, is arranging for publication of the papers in Russia. English versions of all the papers will appear in volume 16 of Vistas in Astronomy. The translation of the Russian papers was made possible by subventions of the International Academy of the History of Science and the IAU.

Of all the Kepler exhibitions, the one at the Deutsches Museum in Munich was probably planned intensively for the longest time. Organized by Dr V. Bialas, the display featured several working models that required many months of preparation. Enlarged copies of early illustrations formed 
a background to the models, graphically revealing the conflicts and superstitions of the 17th century. A small catalog, Gesetz und Harmonie, accompanied the exhibition.

At the British Museum in London, a joint exhibition commemorated the 400th aninversaries of both Kepler and the Dutch map maker Willem Blaeu. The British Society for the History of Science organized a Kepler symposium on 22 October, with E. J. Aiton, R. Leighton Davis, J. Marek, and J. L. Russell as speakers. The Royal Astronomical Society (in collaboration with the Royal Society) commemorated Kepler at their meeting of 10 December with the George Darwin Lecture given by Owen Gingerich and the Sir Harold Jeffreys Lecture given by Desmond KingHele; these lectures have been published in the Quarterly Journal of the Royal Astronomical Society for September 1972.

A Kepler symposium was held in Žagán (Poland) on 23 October, with the following speakers: P. Costabel, E. Rybka, J. Dobrzycki, S. Szpilczýnski, A. Gawel, and W. Voisé.

On 2 December a Kepler symposium in Paris was jointly organized by the Société Astronomique de France, the Centre des Recherches Alexandre-Koyré, and the Centre International de Synthèse, with the following speakers: R. Taton, A. Hayli, F. Russo, B. Morando, P. Costabel, G. Simon, J. Levy, and J. Kovalevsky.

Special Kepler exhibitions were held in the United States at the Burndy Library in Norwalk, Connecticut, and at the University of Texas at Austin; a 52-page catalog, with an introduction by Robert Palter, was issued for this latter exhibition.

A major Kepler quadricentennial program took place in conjunction with the American Association for the Advancement of Science meeting in Philadelphia on 27-28 December. The principal historical papers included:
M. List (G.F.R.)
E. Rosen (U.S.A.)
A. Beer (U.K.)
O. Gingerich (U.S.A.)
I. B. Cohen (U.S.A.)
J. O. Fleckenstein
(Switzerland)
R. Westman (U.S.A.)

\author{
'Kepler as a Man' \\ 'Kepler's Place in History of Science' \\ 'Astrology and Mysticism' \\ 'Kepler's Place in Astronomy' \\ 'Kepler's Century' \\ 'Kepler and Neoplatonism'
}

Other historical papers were given by C. D. Hellman, E. Rybka, S. Drake, H. S. M. Coxeter, R. J. Seeger, D. H. Menzel, and A. A. Mikhailov (read by S. L. Lippincott). These papers will be published in volume 16 of Vistas in Astronomy, edited by Arthur Beer.

Two particularly well-illustrated books appeared for the Kepler year, Johannes Kepler, Dokumente zu Leben und Werk (Munich, 1971), by Walther Gerlach and Martha List, and Johann Kepler, Sein Leben in Bildern und eigenen Berichten (Linz, 1970), by Justis Schmidt. Two other German books are Johannes Kepler/Selbstzeugnisse (Stuttgart, 1971), ausgewählt und eingeleitet von Franz Hammer, übersetzt von Esther Hammer, und erlautert von Friedrich Seck, and Kepler Festschrift 1971 (Regensburg, 1971), edited by Ekkehard Preuss, comprising 12 papers and a short bibliography. An extensive but selected bibliography of recent publications on Kepler will appear soon in the Dictionary of Scientific Biography, volume 7, after the 14000-word article prepared by O. Gingerich.

\title{
VII. COPERNICUS QUINQUECENTENNIAL
}

Foremost among the proposed Copernican anniversary celebrations is the "Colloquia Copernicana', organized by the IUHPS and scheduled in Poland parallel to the symposia associated with the Extraordinary General Assembly. Indeed, the most scientific part of the colloquium, on 'The Astronomy of Copernicus and Its Background', is cooperatively organized as 'The Third Joint Symposium of the IAU and IUHPS'.

The proceedings of the entire Colloquia Copernicana will be published in the Studia Copernicana of the Polish Academy of Science, a series already distinguished by numerous new researches and 
articles on Copernicus, his background, and the influence of his ideas. Another particularly noteworthy undertaking is the production by the Polish Academy of Science of a three-volume Copernican Opera, in simultaneous English, Polish, and Latin editions. The first volume, issued in 1972, contains a careful facsimile of the autograph manuscript of De Revolutionibus, together with a bibliographic commentary.

An impressive number of national and international programs have already been scheduled to celebrate the Copernican quinquecentennial. The UNESCO headquarters in Paris serves as an international clearinghouse for these events, and the UNESCO has organized its own international program in Paris on Copernicus' birthday, 19 February. At the same time an exhibition of historical treasures and astronomical instruments from the Collegium Maius in Krakow will be organized at the Bibliothèque Nationale. In April these same instruments will travel to the Smithsonian Institution in Washington, D. C., to be exhibited in connection with the Smithsonian's fifth international symposium, on 'The Nature of Scientific Discovery'. This major Copernican commemoration is cosponsored by the U.S. National Academy of Sciences and organized with the cooperation of UNESCO.

A symposium on 'Science and Society: Past, Present, and Future' has been planned for the University of Michigan in Ann Arbor, 3-5 April. In Paris a 'Semaine de Synthèse' with the title 'Le Monde de Copernic et Copernic dans Le Monde' has been arranged for the first week of June by the Centre International de Synthèse.

Other Copernican exhibitions have been scheduled at the British Museum in London, the Germanisches Museum in Nuremberg, the Uppsala University Library in Sweden, the Museum of Technology in Warsaw, the Copernican Museum in Rome, and the Jagellonian University Museum in Krakow. A more complete report of exhibitions and programs can be included in a future report of Commission 41 .

\section{ASTRO-ARCHAEOLOGY}

The growing interest in the astronomy of prehistory prompted the Royal Society, in conjunction with the British Academy, to schedule a discussion meeting in London on 'The Place of Astronomy in the Ancient World' on 7-8 December, 1972. An extensive report of the conference appears in the Journal for the History of Astronomy, February 1973, and the fourteen papers will be published by the Royal Society.

A session on 'Archaeoastronomy in Pre-Columbian American' has been scheduled for the Mexico City meeting of the American Association for the Advancement of Science on 20-21 June, 1973.

\section{NEW BOOKS IN THE HISTORY OF ASTRONOMY}

The proposed thirteen-volume Dictionary of Scientific Biography (New York, 1970- ), edited by C. C. Gillispie, has now reached the publication of five volumes, with two additional volumes currently in press. This major international effort will include articles, ranging in length from about 500 to 15000 words, on approximately 800 astronomers. In many cases the associated bibliography represents an especially valuable contribution. Among the major articles published in the first five volumes are al-Battani (W. Hartner), Bessel (W. Fricke), Al-Biruni (E. S. Kennedy), Brahe (D. Hellman), Cassini (R. Taton), Copernicus (E. Rosen), and Galileo (S. Drake). Major articles in press include Hale (H. Wright), Halley (C. Ronan), J. Herschel (D. Evans), W. Herschel (M. Hoskin), Hertzsprung (K. Strand), Hubble (G. Whitrow), Huggins (H. Dingle), and Kepler (O. Gingerich).

E. J. Aiton, The Vortex Theory of Planetary Motions, Macdonald, London, 1972.

G. S. Badalyan, The History of Calendars, Publishing House of the Armenian Academy of Science, Erevan, 1970.

Silvio A. Bedini, The Life of Benjamin Banneker, Charles Scribner's Sons, New York, 1972.

Yu. A. Beljy, Johann Kepler (in Russian), 'Nauka', Moscow, 1971. 
Francis S. Benjamin, Jr. and G. J. Toomer, Campanus of Novara and Medieval Planetary Theory, University of Wisconsin Press, Madison, 1971.

Barbara Bienkowska, Kopernik i heliocentryzm w polskiej kulturze umyslowej do konca XVIII wieku (Nicolaus Copernicus and the Heliocentric Theory in Polish Culture Till the End of the Eighteenth Century), (Studia Copernicana III), Ossolineum, Wroclaw, 1971.

Roger Billard, l'Astronomie Indienne Investigations des Textes Sanskrits et des Donnes Numériques, École Française d'Extrême-Orient, Paris, 1971.

Aleksander Birkenmajer, Etudes d'Histoire des Sciences et de la Philosophie du Moyen Age, (Studia Copernicana I), Ossolineum, Wroclaw, 1970.

R. A. Blondeau, Mandarïn en astronoom Ferdinand Verbiest aan het hof van de Chinese keizer, Brouwer, Utrecht, 1970.

Frans Bruin and Alexander Vondjidis (ed. and transl.), The Books of Autolykos: On a Moving Sphere and On Risings and Settings, American University of Beirut, Beirut, 1971.

Karl Heinz Burmeister, Georg Joachim Rhetikus, Eine Bio-Bibliographie, (3 volumes) Guido Pressler Verlag, Wiesbaden, 1968.

Gunther Buttmann, The Shadow of the Telescope: A Biography of John Herschel, Charles Scribner's Sons, New York, 1970.

Max Caspar (ed.), revised by Martha List, Bibliographia Kepleriana, C. H. Beck, Munich, 1968.

Bina Chatterjee, The Khandakhadyaka (An Astronomical Treatise) of Brahmagupta with the Commentary of Bhattotpala, World Press, Calcutta, 1970.

I. B. Cohen, Introduction to Newton's Principia, Harvard University Press, Cambridge, 1971.

N. Copernicus, De Revolutionibus Orbium Coelestium, (facsimile of Tycho Brahe's annotated copy of the second edition, arranged by Z. Horský), Prague, 1972.

F. della Corte, L'antico calendario dei romani, Bozzi, Genoa, 1969.

Frank W. Cousins, Sundials. A Simplified Approach by Means of the Equatorial Dial, John Baker, London, 1969.

Pawel Czartoryski (ed.), Nicholas Copernicus Complete Works. Vol I: The Manuscript of Nicholas Copernicus' 'On the Revolutions', (facsimile), Macmillan and Polish Scientific Publishers, Cracow, 1972.

D. R. Dicks, Early Greek Astronomy to Aristotle, Thames and Hudson, London, 1970.

Stillman Drake, Galileo Studies-Personality, Tradition, and Revolution, University of Michigan Press, Ann Arbor, 1970.

J. O. Fleckenstein, Die Werke von Jacob Bernoulli, Band 1, Birkhauser Verlag, Basel, 1969.

Eric G. Forbes, Tobias Mayer's Opera Inedita, (the first translation of the Lichtenberg edition of 1775), Macmillan, London, 1971.

Walther Gerlach and Martha List, Johannes Kepler, Dokumente zu Lebenszeit und Lebenswerk, Ehrenwirth Verlag, Munich, 1971.

Bernard R. Goldstein, Al-Bitruji: On the Principles of Astronomy (2 volumes), Yale University Press, New Haven, 1971.

Samuel Guye and Henri Michel, Time and Space. Measuring Instruments from the Fifteenth to the Nineteenth Century, Pall Mall Press, London, 1971.

Tord Hall, C. F. Gauss, A Biography, The MIT Press, Cambridge, 1970.

Franz Hammer (ed.), Johannes Kepler Gesammelte Werke, Vol. X. Tabulae Rudolphinae, C. H. Beck, Munich, 1969.

Willy Hartner, Die Goldhörner von Gallehus, Franz Steiner Verlag GMBH, Wiesbaden, 1969.

G. Hermanowski, Nicolaus Copernicus, sein Leben und sein Werk, Markus-Verlag, Munich, 1971.

Kenneth Heuer, City of the Stargazers, Charles Scribner's Sons, New York, 1972.

Johannes Hevelius and His Catalog of Stars, Brigham Young University Press, Provo, Utah, 1971.

Stanley L. Jaki, The Paradox of Olbers' Paradox: A Case History of Scientific Thought, Herder and Herder, New York, 1969.

Stanley L. Jaki, The Milky Way, An Elusive Road for Science, Science History Publications, New York, 1972.

Bessie Zaban Jones and Lyle Giford Boyd, The Harvard College Observatory: The First Four Directorships, 1839-1919, Harvard University Press, Cambridge, 1971.

Kenneth Glyn Jones, Messier's Nebulae and Star Clusters, Faber and Faber Ltd., London, 1968.

Johannes Kepler, Selbstzeugnisse, ausgewählt und eingeleitet von Franz Hammer, übersetzt von Esther Hammer, erläutert von Friedrick Sech, Friedrich Frommann Verlag, Stuttgart-Bad Cannstat, 1971.

P. G. Kulikovsky (ed.), Studies on the History of Astronomy, Volume 11 (19 articles in Russian), 'Nauka', Moscow, 1972.

Jack Lindsay, Origins of Astrology, Barnes \& Noble, Inc., New York, 1971. 
William McGucken, Nineteenth Century Spectroscopy. Development of the Understanding of Spectra 18021897, Johns Hopkins Press, Baltimore, 1969.

Ernan McMullin (ed.), Galileo, Man of Science, Basic Books, Inc., New York, 1967.

Yasukatsu Maeyama, Hypothesen zur Planetentheorie des 17. Jahrhunderts, Institut für Geschichte der Naturwissenschafts, Johann Wolfgang Goethe-Universität, Frankfurt am Main, 1971.

Miecziplaw Markowski, Burydanizin w Polsce w okresie przedkopernikanskim (Buridanism in Poland Before Copernicus), (Studia Copernicana II), Ossolineum, Wroclaw, 1971.

A. J. Meadows, The High Firmament, Leicester University Press, Leicester 1969.

A. J. Meadows, Early Solar Physics, Pergamon, Oxford, 1970.

A. J. Meadows, Science and Controversy, a Biography of Sir Norman Lockyer, The MIT Press, Cambridge, 1972.

Patrick Moore, The Astronomy of Birr Castle, Mitchell Beazley, London, 1971.

Antoine Mostaert, Manual of Mongolian Astrology and Divination, Harvard University Press, Cambridge, 1969.

Robert R. Newton, Ancient Astronomical Observations and the Accelerations of the Earth and Moon, The Johns Hopkins Press, Baltimore, 1970.

Robert R. Newton, Medieval Chronicles and the Rotation of the Earth, The Johns Hopkins Press, Baltimore, 1972.

M. M. Nieto, The Titius-Bode Law of Planetary Distances, Pergamon Press, London, 1973.

Wilhelm Norlind, Tycho Brahe: A Biography, (in Swedish, with German summary), Gleerup, Lund, 1970.

J. D. North, Kalenderes Enlumyned Ben They: Some Astronomical Themes in Chaucer, Museum of the History of Science, Oxford, 1969.

Nicole Oresme, Le Livre du Ciel et du Monde, University of Wisconsin Press, Madison, 1968.

Antoninette Mann Paterson, The Infinite Worlds of Giordano Bruno, Charles C. Thomas, Springfield, 1970.

David Pingree, Census of the Exact Sciences in Sanskrit, (2 volumes), American Philosophical Society, Philadelphia, 1970, 1971.

Ekkehard Preuss (ed.), Kepler Festschrift 1971, Naturwissenschaftlicher Verein, Regensburg, 1971.

Edward Rosen, Three Copernican Treatises, Octagon Books, New York, 1971.

Giorgio de Santillana and Hertha von Dechend, Hamlet's Mill, Gambit, Boston, 1969.

Justus Schmidt, Johann Kepler sein Leben in Bildern und eigenen Berichten, Rudolf Traumer Verlag, Linz, 1970.

Barbara J. Shapiro, John Wilkins, 1614-1672: An Intellectual Biography, University of California Press, Berkeley, 1970.

William R. Shea, Galileo's Intellectual Revolution, Middle Period, 1610-1632, Science History Publications, New York, 1972.

Loyd S. Swenson, The Ethereal Aether, University of Texas Press, Austin, 1972.

Alexander Thom, Megalithic Lunar Observatories, Oxford University Press, Oxford, 1971.

Diedrick Wattenberg, Peter Apianus and His Astronomicum Caesareum, (an accompanying volume to a facsimile reprint of the Astronomicum Caesareum), Edition Leipzig, 1967.

Bruno Weber, Erschröckliche und warhafftige Wunderzeichen, (color facsimiles of 20 astronomical broadsides from 1543 to 1586), Urs Graf-Verlag Dietikon, Ziirich, 1971.

Charles A. Whitney, The Discovery of Our Galaxy, Alfred A. Knopf, New York, 1971.

Helen Wright, Joan N. Warnow, and Charles Weiner, The Legacy of George Ellery Hale, The MIT Press, Cambridge, 1972.

Thomas Wright, Clavis Coelestis, being the Explication of a Diagram entitled a 'Synopsis of the Universe: or, the Visible World Epitomized', (preface by M. A. Hoskin), Dawsons, London, 1967.

Thomas Wright, Second or Singular Thoughts Upon the Theory of the Universe, (M. A. Hoskin, ed.), Dawsons, London, 1968.

Thomas Wright, An Original Theory of New Hypothesis of the Universe, (facsimile reprint with introduction and transcription by M. A. Hoskin), Macdonald, London, 1971.

Kiyoshi Yabuuchi, Chügoku no tenmon rekihö (Chinese astronomy and calendrical science), (in Japanese), Heibonsha, Tokyo, 1969.

O. GINGERICH

President of the Commission 